rock and its locality, and a larger descriptive label set lectern fashion on an upright post, are provided, and a brief geological history of the country is available at the nearby branch museum.

\section{Evaporation from Grass and Vegetables}

Penman's method of ealculating from past temperature, rainfall and sunshine the amount of water necessary in irrigation to replace that lost by evaporation is based on experimental evidence for evaporation from grass. It has been hitherto assumed, in the application of the method, that the evaporation from other crops is the same as that from grass. N. E. Rider, of the Meteorological Office, working in the School of Agriculture, Cambridge, measuring the evaporation from bare soil, grass, peas and brussels sprouts during the early summer of 1955, found it was on some days much greater from the peas and sprouts than from grass. During the afternoon of June 18 the rate of evaporation from peas was equivalent to a water loss of $7.4 \mathrm{~mm}$. a day, more than ten times the rate of $0.6 \mathrm{~mm}$. a day from grass and the $0.4 \mathrm{~mm}$. a day from soil. The rate from dry, bare soil was less than from grass. Both peas and sprouts formed a continuous cover over the ground. The rate of evaporation was not measured directly but by computation from Thornthwaite and Holzman's aerodynamic formula relating it to differences of wind speed and water content in the vertical direction immediately above the crop. The necessary delicate readings of wind and humidity were made with three types of apparatus, and most of Rider's paper (Quart. J. Roy. Meteor. Soc., 83, $181 ; 1957)$ is devoted to justifying the accuracy of the observations. On one afternoon the rate of evaporation was about twice that for which energy could be provided by the intensity of sunshine measured at the nearest station, 60 miles away at Kew, but no error could be found in the instruments. Rider's work is of agricultural importance for deciding how much water to provide in irrigation.

\section{Lethal Effects on Plant Cells of Fungal and Bacterial Extracts}

A FURTher contribution to this theme comes from S. G. Fushtey (Annals of Botany, N.S., 21, 273; 1957). When cucumber and turnip tissues were subjected to enzyme preparation of Botrytis cinerea and Bacterium aroideae in the presence of plasmolysing concentrations of various crystalloids, killing of cells was retarded out of all proportion to the slight retarding effect on maceration. When the tissue cells were recovered from plasmolysis they regained their sensitiveness to the toxic action. Toxicity of mercuric chloride and oxalic acid was also much reduced when cells were plasmolysed. Fractional precipitation with various proportions of acetone and over a wide range of $p \mathrm{H}$ gave preparations which varied in activity from one treatment to another, but their macerating and toxic actions varied together. After partial maceration, plant tissues were much more sensitive to the toxic action of mercuric chloride or oxalic acid. This is interpreted as meaning that, before maceration is complete, the toxic principle has been able to reach the protoplastic surface and to exert a deleterious effect upon it. The evidence presented gives further support to the view that the enzyme system of the two pathogenie organisms which macerates the host cell walls also brings about death of the protoplasts.

\section{Brown Library, Liverpool}

To mark the unveiling by H.M. Queen Elizabeth the Queen Mother on June 25 of a plaque commemorating the commencement of the rebuilding of the Brown Library as part of the celebrations of its centenary and of the 750th anniversary of the creation of Liverpool as a borough, the City Librarian, Dr. G. Chandler, has compiled an illustrated booklet (Centenary of the Brown Library and its Satellites, 1857-1957. Pp. 24. Liverpool: Central Public Libraries, 1957) recording the development of the several central libraries of Liverpool, all named after benefactors, and other principal donations to the Liverpool City Libraries. Besides the Brown Library itself, opened in 1860 and named after Sir William Brown, there are the Picton Reference Library, opened in 1879 and named after Sir James A. Picton, and the Hornby Library, presented by Mr. H. F. Hornby and opened in 1906. The Oak Library, opened in 1914, was built to house some of the most valuable books given to the city or acquired by special purchase, and the Commercial Library, opened in 1917, was considerably expanded in 1955 . Rebuilding of the Brown Library will cost more than $£ 400,000$, and the area devoted to the temporary Technical Library (opened in 1952) will be used for the Record Office and local history collections when the Hunter Street block is built. The new modern building is expected to contain the permanent technical and patents libraries; the general reading room to replace the Christian Street library; a Central junior library with meeting and exhibition rooms; a lecture theatre to seat 850 , which could also be used for public meetings; a large exhibition hall; staff and stock rooms; and accommodation for the Parents--Teachers-Youth collections temporarily housed in Blue Coat Chambers. The anniversary is also marked by an exhibition of books, manuscripts, water-colours and prints in the International Library, Central Public Libraries, during June 17 to September 28 .

\section{International Scientific Radio Union}

The twelfth General Assembly of the International Scientific Radio Union (U.R.S.I.) will be held at Boulder, Colorado, during August 22-September 5, by invitation of the U.S. National Committee of the Union and the U.S. National Academy of Sciences. Accounts of the previous meeting at 'The Hague in 1954 and of reports of its proceedings were given in Nature for September 3, 1955, p. 451, April 7, p. 652, and September 8,1956, p. 528. Plans for the forthcoming meeting at Boulder have already been announced by the United States organizing committee under the chairmanship of Dr. J. H. Dellinger, honorary president of the International Scientific Radio Union. These include preliminary agenda for meetings of the seven commissions dealing, respectively, with radio measurements and standards, tropospheric and ionospheric propagation, noise of terrestrial origin, radio astronomy, and waves, circuits and electronics. The president of the International Scientific Radio Union for the General Assembly is Father P. Lejay (France). The Union is composed of national committees which contribute by subscription to its income and, as a result, are entitled to official representation and participation in its scientific work before and during each General Assembly. The British National Committee for Scientific Radio is organized under the auspices of 